Гарнага О. М. [1; ORCID ID: 0000-0002-5236-7299], к.е.н., доцент

${ }^{1}$ Національний університет водного господарства та природокористування, м. Рівне

\title{
СУЧАСНІ ТЕНДЕНЦІЇ МІЖНАРОДНОГО ТРАНСФЕРУ ІННОВАЦІЙНИХ ТЕХНОЛОГІЙ
}

У статті розглянуто сучасні тенденції міжнародного трансферу інноваційних технологій. Доведено, що на міжнародному рівні транснаціональні компанії є стимуляторами імміграційних процесів, дистриб'юторами новітніх інформаційних технологій. Вони є стрижнем глобальних інновацій, що визначає темпи та напрямки розвитку світового ринку. При цьому важливо зазначити, що науковці виділяють три фундаментальні моделі інноваційних систем як на рівні підприємств, так $\mathbf{i}$ на рівні держав: американську, європейську та азійську.

Ключові слова: інноваційні технології; транснаціональні компанії; інноваційна стратегія; міжнародний трансфер; венчурні підприємства.

Вступ. Сучасний світ характеризується різноманітністю норм, цінностей, способів життя та культур, а також зростаючою потребою у товарах і послугах, що відповідає цим змінам. За останні десятиліття світова економіка зазнала суттєвих змін. Ці зміни головним чином пов'язані з діяльністю транснаціональних компаній, які сприяли швидкому фінансовому та економічному розвитку. У підсумку, основною діяльністю стала діяльність транснаціональних компаній, для яких міжнародний бізнес став відігравати більше значення ніж внутрішня діяльність.

На міжнародному рівні транснаціональні компанії зараз $€$ торговцями, стимуляторами імміграційних процесів, дистриб'юторами новітніх інформаційних технологій. Вони $\epsilon$ стрижнем глобальних інновацій, що визначає темпи та напрямки розвитку світового ринку. Зрештою, інноваційна стратегія компанії багато в чому визначає конкурентоспроможність транснаціональних компаній на світовому ринку. В контексті прискореного розвитку інформаційного суспільства однією 3 основоположних функціональних стратегій конкуренції транснаціональних компаній $€$ стратегія використання найважливішого нематеріального активу інновації. Сьогодні на світовому інноваційному ринку 
транснаціональні корпорації працюють в динамічному, агресивному та багатогранному конкурентному середовищі.

Аналіз останніх досліджень і публікацій. Дослідження аспектів стратегічного розвитку держав на інноваційній основі, визначення процедур, методів, алгоритмів стратегічного управління постійно перебувають у центрі уваги зарубіжних та українських науковців, зокрема В. Аньшина, Дж. Брайта, Дж. Даннінга, Дж. Ендрю, Р. Кана, Дж. М. Кейнса, Дж. Кендалла, Л. Гохберга, П. Завліна, Ю. В. Яковца, В. Гейця, В. Семиноженка та інших учених. Проте, звісно, що багато питань лишаються ще не до кінця дослідженими і потребують поглибленої розробки теоретичних і методологічних аспектів щодо вивчення міжнародного трансферу інноваційних технологій.

Постановка завдання. Мета статті полягає в дослідженні новітніх тенденцій міжнародного трансферу інноваційних технологій.

Викладення основного матеріалу. Інноваційна діяльність $€$ специфічною категорією в економіці, що відрізняється від інноваційного процесу. Якщо вважати, що інноваційний процес - це зміна фаз і етапів життєвого циклу інновацій, то інноваційна діяльність $є$ рушієм цих змін. Класики інноватики, до яких відносять: Й. Шумпетера, К.Фрімена, А. Кляйкнехта, наголошували на ролі інноваційної діяльності міжнародних компаній у активізації інноваційних процесів.

Огляд і аналіз досліджень науковців [1-5], які вивчали аспекти комерціалізації високотехнологічної продукції, дозволяють виділити три фундаментальні моделі інноваційних систем як на рівні підприємств, так і на рівні держав: американську, європейську та азійську. Не дивлячись на економічну просторову розбіжність всі ці моделі мають схожі елементи формування, а отже, і спільні складові.

У США, Азії та Європі транснаціональні компанії використовують новітні методи та механізми трансферу технологічних розробок: продають ліцензії на початкових стадіях життєвого циклу товару, щоб дати час компенсувати частину витрат на дослідження та розробку; встановлюють завищені ціни на запатентований товар та юридично обмежують випуск високотехнологічної продукції покупцями ліцензій тощо.

Усі без винятку транснаціональні компанії заохочують створення в своїх структурах малих венчурних компаній, які існують за рахунок внутрішніх венчурних фондів. Вперше практика організації ризиків з'явилася в США в середині 70-х років. Наприклад, відома компанія General Electric керує 30 венчурними компаніями в різних стратегічних сферах [8]. Їх капітал перевищує 
100 мільйонів доларів США. Компанія Xerox створила відділ венчурного капіталу в сфері технологій на суму понад 30 мільйонів доларів, до якого інженери або інший персонал можуть звертатися для підтримки своїх незалежних інноваційних проектів, для створення та розвитку високотехнологічних продуктів.

Географічне розташування дослідницьких центрів та венчурних компаній залежить від фінансових та адміністративних переваг регіону, а також кваліфікації персоналу в ньому. Існує також багато фактів про створення іноземних компаній венчурного капіталу в США. Перша причина полягає в тому, що $€$ на порядок більше можливостей у наступних сферах: забезпечення фінансування бізнес-процесів, пов'язаних зі створенням та комерціалізацією високотехнологічних продуктів та рівнем оподаткування венчурних компаній.

Переважна більшість венчурних компаній знаходиться в технологічних парках, технологічних містах, бізнес-інкубаторах та інших інноваційних структурах. У світі існує понад 500 техноутворень. У США більше 160, близько 50 у Японії, понад 50 у Китаї, 46 у Великобританії, понад 50 у Франції. Понад 100 науковотехнологічних парків розташовуються у Центральній та Східній Європі.

Комерціалізація високотехнологічної продукції починається 3 урахування регіональних особливостей попиту на нові товари та забезпечення всіх умов для швидкого повернення інвестицій.

Хоча тенденція до розвитку інновацій та інтернаціоналізації $€$ загальною для більшості транснаціональних компаній у світі, конкретні стратегії, прийняті японськими, американськими та європейськими компаніями, досить різняться. Це пояснюється не лише чисто економічними міркуваннями, а й пріоритетами економічної політики конкретної держави.

Так, наприклад, європейські транснаціональні компанії користуючись перевагами законодавства Європейського Союзу розміщують свої лабораторії у європейських країнах, де зібрано висококваліфікований персонал. Наприклад, компанія АBB, що утворилася з об'єднання компаній Azea (Швеція) та Brown Boweri (Швейцарія), створила новий центр досліджень енергетики не у Швеції чи Швейцарії, а в Німеччині, де можна знайти відповідних високоякісних експертів.

Японські компанії, як правило, закриті та консервативні, що відповідає зовнішньоекономічній стратегії Японії. Вони, зазвичай, зосереджують свою дослідницьку діяльність у себе в країні і лише 
використовують іноземні лабораторії для досліджень та розробок на завершальній стадії комерціалізації інновацій, щоб адаптувати вже готову продукцію або технологію до місцевих стандартів та оптимізувати їх відповідно до місцевих ринків.

Американські компанії в більшості чинять прагматичніше при розміщенні дослідницьких підрозділів на території США. Сьогодні в США існують сприятливі умови для інновацій: продумане законодавство, пільгове оподаткування НДДКР, велика кількість венчурного капіталу, зрілі інноваційні механізми комерціалізації та високоякісні таланти з усього світу. Однак на початку XXI ст. тут почала спостерігатися нова тенденція. Тут почали під керівництвом прагматичної мотивації для розробки, виробництва та реалізації продукції створювати наукові установи в Європі та деяких країнах Азії. Така регіональна різниця призводить до існування декількох способів інтернаціоналізації інноваційної діяльності транснаціональних компаній шляхом створення іноземних науководослідних лабораторій.

Японські транснаціональні компанії зазвичай приймають план, що складається з п'яти послідовних етапів.

Першим кроком $€$ підготовка технологій, пов'язаних 3 інтернаціоналізацією товарів, тобто підготовка їх до імпорту на зовнішні ринки. Компанія орієнтована на науково-технічну інформацію про продукт та можливості щодо його впровадження, в тому числі в Японії, вона зазвичай відкриває окремі офіси в США та Європі, і ці офіси займаються лише технічним моніторингом. Японські компанії, укомплектовуючи ці офіси, як правило, покладаються тільки на своїх співвітчизників.

Другий етап передбачає створення організаційної системи для підтримки передачі технологій на виробничі потужності за кордоном. Більшість компаній формують спеціальний технічний відділ, тобто стандартну японську модель. Кожна велика компанія підтримується технічним відділом або лабораторією, що сприяє розвитку технологій та вдосконаленню продукції.

У деяких компаніях, хоч виробництво нової продукції все ще зосереджено в Японії, відокремлені підрозділи вносять незначні модифікації продуктів, щоб адаптуватися до місцевого ринку.

На третьому етапі в багатьох японських компаніях закордонні лабораторії проводять лише порівняно невеликі дослідження. їх основна діяльність - виконання широкого кола завдань: технічна співпраця 3 постачальниками, підтримка передачі технологій у виробництво та перехресне ліцензування. 
На четвертому етапі іноземні дослідницькі лабораторії зосереджуються на розробці нових продуктів (головним чином для місцевого ринку). Іншими словами, зрештою, починається справжня робота, спрямована на створення нових знань, офіційно визначених як інтернаціоналізація інноваційної діяльності компанії.

П'ятий етап, до якого доходять лише деякі найбільші компанії, розширяє стратегічні завдання зарубіжних дослідних центрів. На цьому етапі їх сфера діяльності охоплює фундаментальні дослідження.

Європейські та американські компанії використовують простіші рішення для створення іноземних дослідницьких підрозділів.

На першій фазі створюють відділ передачі технологій, в якому продукція та технології виробництва, які потребують подальшого вдосконалення, передаються від материнської компанії до виробничої галузі.

Друга фаза характеризується створенням місцевого технічного відділу, тобто закордонної лабораторії, яка орієнтована лише на місцевий ринок і займається створенням інноваційних продуктів лише в основному бізнесі материнської компанії.

На третій фазі закордонні лабораторії отримують статус глобального технологічного відділу, відповідального за розробку нових продуктів для світового ринку. Межі іноземних науководослідних центрів знову визначаються материнською компанією, яка наказує своїм лабораторіям визначити пріоритетні напрямки досліджень та забезпечити їм необхідну теоретичну розробку.

У процесі накопичення необхідного потенціалу знань, чудового технічного рівня та успішної роботи на попередньому етапі на базі технічного відділу здійснюється четверта фаза розвитку іноземної лабораторії. Тепер, коли іноземні лабораторії мають певний ступінь незалежності, вони можуть обрати пріоритетні напрямки для розробки товарів та провести необхідні фундаментальні дослідження для створення інноваційних продуктів та технологій для материнської компанії для продажу на світовому ринку.

Слід зазначити, що існують принципові відмінності між виробничими планами японських транснаціональних корпорацій та американськими транснаціональними корпораціями та інноваційною продукцією країн європейського союзу.

Тому на відміну від транснаціональних компаній у США та Європейському Союзі, японські транснаціональні компанії характеризуються поступовою інтеграцією до країни, де розташовані iї іноземні дослідницькі лабораторії, щоб поступово готуватися до 
виробництва у приймаючій країні. Більше того, будь-які попередні етапи - це лише підготовка до майбутнього виробництва. Характеристикою транснаціональних компаній у США та Європейському Союзі $є$ поступова трансформація науково-дослідних лабораторій із повністю залежних (відносно материнської компанії) у відносно незалежні лабораторії, які лише покладаються на материнську лабораторію для деяких інноваційних замовлень на продукцію.

Вищезазначені відмінності В характеристиках моделей інноваційного розвитку в США, Європі та Азії свідчать про унікальні конкурентні переваги транснаціональних компаній, тому рекомендується виділити деякі відмінності між ними. Перш за все, ми говоримо про сучасну тенденцію країн Азії, особливо Індії, Китаю та Південної Кореї, пропонувати високотехнологічну продукцію на ринку за заниженими цінами. У технологічних парках цих країн створюються недорогі високотехнологічні продукти [6].

Здатність американських компаній розробляти та комерціалізувати високотехнологічну продукцію також унікальна. Сьогодні жодна країна світу не здатна інвестувати стільки коштів в інновації та розвиток, як США.

Слід пам'ятати, що для більшості транснаціональних компаній США $є$ батьківщиною. Цей фактор має дуже важливий вплив на конкурентоспроможність американської продукції на світовому ринку, розвиток інноваційної інфраструктури та характер міжнародного науково-технічного співробітництва. У сфері інновацій часто фігурують приватні інвестори, які інвестують в інноваційні проекти, тобто так звані стартапи на етапі створення бізнесу в обмін на частку в капіталі. Приватні інвестори, зазвичай, інвестують власні кошти на відміну від венчурних фондів та банків, що управляють сторонніми фінансовими ресурсами [1]. Експерти стверджують, що більшість приватних інвесторів - це громадяни США. Саме вони шукають нові інновації по всьому світі і стають їх власниками або співвласниками на ранніх стадіях комерціалізації.

Вони часто перепродають права на високотехнологічні продукти банками та фондами або транснаціональним компаніям.

Поєднання глобальних методів та задоволення місцевих інтересів визначає вибір місця своєї діяльності транснаціональними компаніями та альтернативні шляхи технологічного розвитку, методи планування та фінансування міжнародних досліджень та розробок, а також методи управління персоналом в міжнародному середовищі. 


\section{Після складного розвитку та еволюції провідні} транснаціональні компанії стали важливими гравцями у міжнародному бізнесі. Систематично впроваджуючи інновації у виробничу, фінансову та маркетингову діяльність, особливо у високотехнологічних галузях, провідні транснаціональні компанії стали локомотивами впровадження науково-технічної революції. Інноваційний процес транснаціональних компаній набрав найбільшого імпульсу за останні 30 років. 3 одного боку, це пов'язано $з$ формуванням інноваційних стратегічних альянсів, 3 іншого боку, це інтернаціоналізація підтримки фінансування НДДКР та передача технологій.

Сучасні інформаційні технології забезпечують інтеграцію новітніх знань, науки та виробництва двома пов'язаними напрямками: внутрішній - за рахунок вищого ступеня взаємодії науки і техніки компанії з своїми підрозділами у міжнародному інноваційному процесі та зовнішній - розширення зв'язку між транснаціональними компаніями та місцевим бізнесом i організаціями.

Висновки. Отже, В статті розглянуто сучасні тенденції міжнародного трансферу інноваційних технологій. Встановлено, що сфера інновацій все більше привертає увагу транснаціональних компаній, оскільки вона має найважливішу конкурентну перевагу, що має довгострокові наслідки для ринків та держав світу. Зазначено, що сформульована стратегія інноваційної діяльності може формувати технологічну політику транснаціональної компанії відповідно до ринкової позиції та завдань їі розвитку. Насправді технологічна політика транснаціональної компанії визначається багатьма факторами, а їі реалізація пов'язана із взаємодією учасників з різними, а іноді навіть і протилежними інтересами.

1. Губайдуллина Ф. С. Крупные транснациональные корпорации на новых рынках. ЭКО. 2007. № 3. С. 20-33. 2. Ляшенко О. М. Моделі комерціалізації та трансферу технологій в умовах глобального середовища: монографія. Тернопіль : Економічна думка. 2007. 366 с. 3. Ляшенко 0. Підхід до дослідження впливу структури галузевого ринку на інноваційну активність підприємств. Актуальні проблеми економіки. 2010. В. 4. С. 17-24. 4. Нагачевська Т. В. Сучасні тенденції міжнародного трансферу технологій та перспективи України. URL: nbuv.gov.ua (дата звернення: 10.01.2021). 5. Чуйко О. Науково-теоретичні основи інновацій та інноваційного процесу: сутність, види, еволюція. Економіка. 2008. № 2. С. 7-13. 6. Шумпетер Й. Теория экономического развития. М. : Прогресс, 1982. 455 c. 7. Freeman C. As Time Goes By. From the Industrial Revolutions to the Information Revolution. Oxford: Oxford University Press, 2001. 8. Kleinknecht A. Innovation patterns in crisis and prosperity: Schumpeter's long cyrcle reconsidered. Hong Kong, 1987. 203 p. 9. Mensh G. Stalemate in technology: innovation overcome the depression. Cambrige (Mass). 1979.714 p. 


\section{REFERENCES:}

1. Gubaydullina F. S. Krupnyie transnatsionalnyie korporatsii na novyih ryinkah. EKO. 2007. № 3. S. 20-33. 2. Liashenko 0. M. Modeli komertsializatsii ta transferu tekhnolohii $v$ umovakh hlobalnoho seredovyshcha : monohrafiia. Ternopil : Ekonomichna dumka. 2007. 366 s. 3. Liashenko 0. Pidkhid do doslidzhennia vplyvu struktury haluzevoho rynku na innovatsiinu aktyvnist pidpryiemstv. Aktualni problemy ekonomiky. 2010. V. 4. S. 17-24. 4. Nahachevska T. V. Cuchasni tendentsii mizhnarodnoho transferu tekhnolohii ta perspektyvy Ukrainy. URL: nbuv.gov.ua (data zvernennia: 10.01.2021). 5. Chuiko 0. Naukovo-teoretychni osnovy innovatsii ta innovatsiinoho protsesu: sutnist, vydy, evoliutsiia. Ekonomika. 2008. № 2. S. 7-13. 6. Shumpeter Y. Teoriya ekonomicheskogo razvitiya. M. : Progress, 1982. $455 \mathrm{~s}$. 7. Freeman C. As Time Goes By. From the Industrial Revolutions to the Information Revolution. Oxford: Oxford University Press, 2001. 8. Kleinknecht A. Innovation patterns in crisis and prosperity: Schumpeter's long cyrcle reconsidered. Hong Kong, 1987. 203 p. 9. Mensh G. Stalemate in technology: innovation overcome the depression. Cambrige (Mass). 1979. $714 \mathrm{p}$.

Harnaha O. M. [1; ORCID ID: 0000-0002-5236-7299], Candidate of Economics (Ph.D.), Associate Professor

${ }^{1}$ National University of Water and Environmental Engineering, Rivne

\section{CURRENT TRENDS IN THE INTERNATIONAL TRANSFER OF INNOVATIVE TECHNOLOGIES}

The article considers current trends in the international transfer of innovative technologies. It has been proven that at the international level, multinational companies are stimulators of immigration processes, distributors of the latest information technologies. They are the core of global innovation, which determines the pace and direction of development of the world market. Today, in the global innovation market, multinational corporations operate in a dynamic, aggressive and multifaceted competitive environment. It is important to note that scientists distinguish three fundamental models of innovation systems, both at the enterprise level and at the state level: American, European and Asian.

Unlike multinational companies in the United States and the European Union, Japanese multinational companies are characterized by gradual integration into the country where their foreign research laboratories are located in order to gradually prepare for production in the host country. Moreover, any preliminary stages are only a preparation for future production. Transnational companies in the United States and the European Union are characterized by the gradual transformation of research laboratories from fully dependent (relative to the parent company) to 
relatively independent laboratories, which only rely on the parent laboratory for some innovative product orders.

The above differences in the characteristics of innovation development models in the United States, Europe and Asia indicate the unique competitive advantages of multinational companies.

It has been established that the sphere of innovation is increasingly attracting the attention of multinational companies, as it has the most important competitive advantage, which has long-term consequences for markets and countries around the world. It is noted that the formulated strategy of innovation can shape the technological policy of a multinational company in accordance with the market position and objectives of its development. In fact, the technology policy of a multinational company is determined by many factors, and its implementation involves the interaction of participants with different and sometimes even opposing interests.

Keywords: innovative technologies; transnational companies; innovation strategy; international transfer; venture enterprises.

Гарнага А. Н. [1; ORCID ID: 0000-0002-5236-7299], к.э.н., доцент

${ }^{1}$ Национальный университет водного хозяйства и природопользования, г. Ровно

\section{СОВРЕМЕННЫЕ ТЕНДЕНЦИИ МЕЖДУНАРОДНОГО ТРАНСФЕРА ИННОВАЦИОННЫХ ТЕХНОЛОГИЙ}

В статье рассмотрены современные тенденции международного трансфера инновационных технологий. Доказано, что на международном уровне транснациональные компании являются стимуляторами иммиграционных процессов, дистрибьюторами новейших информационных технологий. Они являются стержнем глобальных инноваций, определяют темпы и направления развития мирового рынка. При этом важно отметить, что ученые выделяют три фундаментальные модели инновационных систем как на уровне предприятий, так и на уровне государств: американскую, европейскую и азиатскую.

Ключевые слова: инновационные технологии; транснациональные компании; инновационная стратегия; международный трансфер; венчурные предприятия.

Отримано: 13 січня 2021 р. 